\title{
An Enhanced UHPC-Grout Shear Connection for Steel-Concrete Composite Bridges with Precast Decks
}

\author{
Yongtao Zhang $\mathbb{D}^{1},{ }^{1}$ Hehui Zheng, ${ }^{2}$ Minghao Tang, ${ }^{3}$ and Zhiqi He $\mathbb{i D}^{3}$ \\ ${ }^{1}$ College of Civil Engineering, Tongji University, Shanghai 200092, China \\ ${ }^{2}$ CCCC Second Harbour Engineering Co., Ltd., Wuhan 430040, China \\ ${ }^{3}$ School of Civil Engineering, Southeast University, Nanjing 211189, China \\ Correspondence should be addressed to Yongtao Zhang; kiptom@vip.163.com
}

Received 15 January 2021; Revised 28 April 2021; Accepted 11 May 2021; Published 26 May 2021

Academic Editor: Cristoforo Demartino

Copyright (c) 2021 Yongtao Zhang et al. This is an open access article distributed under the Creative Commons Attribution License, which permits unrestricted use, distribution, and reproduction in any medium, provided the original work is properly cited.

\begin{abstract}
This article develops an enhanced UHPC-grout shear connection for steel-concrete composite bridges with precast decks. The primary improvement is the use of ultra-high performance concrete (UHPC) as the connection grout. To validate the constructability and the mechanical performance of the new connection, two series of experimental tests (including grouting tests and push-out tests) were conducted. Results from the grouting tests show that both the pressure grouting method and the self-levelling grouting method are applicable to inject the UHPC grout into the channel void of the connection. Results from the push-out tests indicate that the advanced properties of UHPC allow for a significant improvement of the shear resistance of the adhesive connection over traditional cementitious grouts. The ultimate shear capacity of the adhesive connection is controlled by the interface shear strength between the embossed steel and the UHPC grout, with a cohesion value of approximately $5.87 \mathrm{MPa}$. Meanwhile, the residual frictional resistance can be taken as approximately one-half of the ultimate resistance. The results of the finite-element analysis show that the trilinear model is reasonable to simulate the shear-slip laws of the embossed steel-grout interface and the rough concrete-grout interface.
\end{abstract}

\section{Introduction}

Steel-concrete composite bridges using prefabricated fulldepth deck panels allow modular construction and greatly minimizing traffic impacts. Shear stud clusters embedded in shear pockets are usually used to create composite action between concrete deck slabs and steel girders (Figure 1). This type of connection has been proven effective for shear transfer and achieving composite action. However, the use of connectors embedded in closely spaced pockets can present some problems identified by Badie et al. [1] and Haber et al. [2], which include constructability challenges due to fit-up issues, nonuniform force distribution within the stud cluster, and bearing failure of concrete in front of the stud cluster.

One potential solution to these problems is the use of linear or surface connections rather than point connections. One promising detail is the "connection by adhesion, interlocking, and friction" (also referred to as "adhesive connection") that was first proposed by Thomann [3] from EPFL in Switzerland, with further modifications by several researchers. The first generation of the adhesive connection is shown in Figure 2(a), which is fabricated by performing a roughened slot in the lower part of the concrete deck slab, welding an embossed steel rib longitudinally to the upper flange of the steel girder, and casting the strip void between the slot and the steel rib with cement grout. The resistance of the connection to longitudinal shear is based on the development of shear stresses in the confined interfaces. This connection usually exhibits less ductile behavior in comparison with the shear studs. The interface shear behavior of this connection under static and cyclic loading and theoretical constitutive laws of confined grouted interfaces were thoroughly investigated by Thomann and Lebet [4] and Papastergiou and Lebet [5]. 


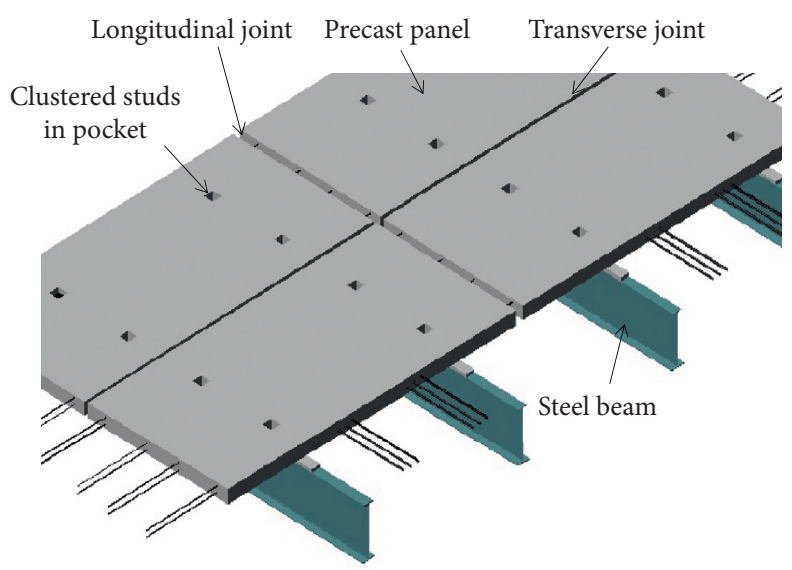

Figure 1: Full-depth precast deck system with stud clusters as the shear connection.

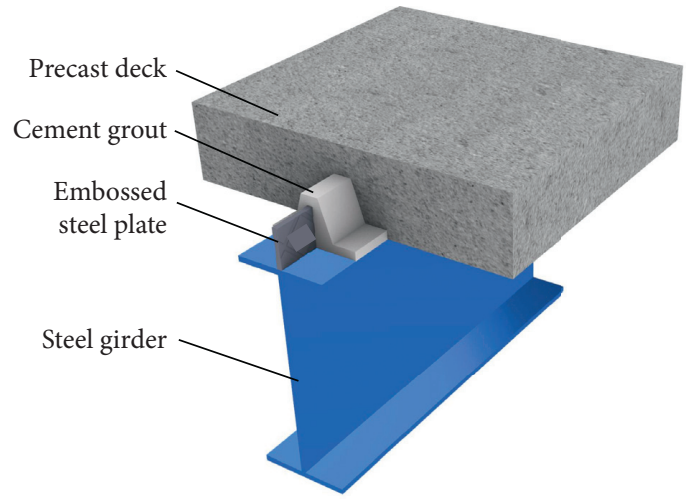

(a)

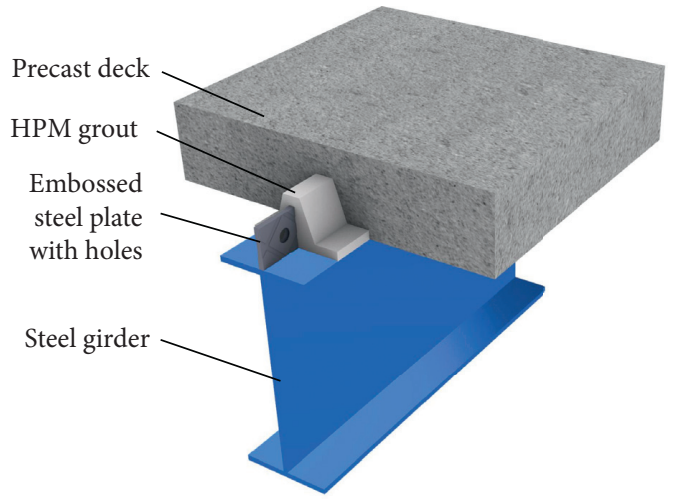

(b)

Figure 2: Details of adhesive connection: (a) first generation; (b) second generation.

The second generation of the adhesive connection is shown in Figure 2(b) by Diógenes et al. [6], with the use of high-performance mortar (HPM) and the presence of circular holes in the steel rib to generate a "dowel effect." As shown in Figure 3, this idea comes from the Perfobond shear connectors, in which the shear resistance is expected to be increased considering the confined concrete inside the connector's openings. Flexural tests of composite beams using the improved adhesive connection were also conducted by Diógenes et al. [7]. The test results showed that the presence of holes in the connectors had a limited contribution to the flexural stiffness and the loading capacity of the specimens.

The resistance of the adhesive connection to longitudinal shear is dependent on the adhesion and friction between the connected materials. A significant amount of research has already been carried out on interface behavior. For the interface between the embossed steel plate and cement paste, Thomann and Lebet [4] developed a model capable of describing the behavior of the interface loaded in shear and subjected to variable compressive stresses. Minafò [8] and Campione et al. [9] suggested the values be adopted for the constitutive law of steel-to-concrete interface, including the cohesion, the friction coefficient, and

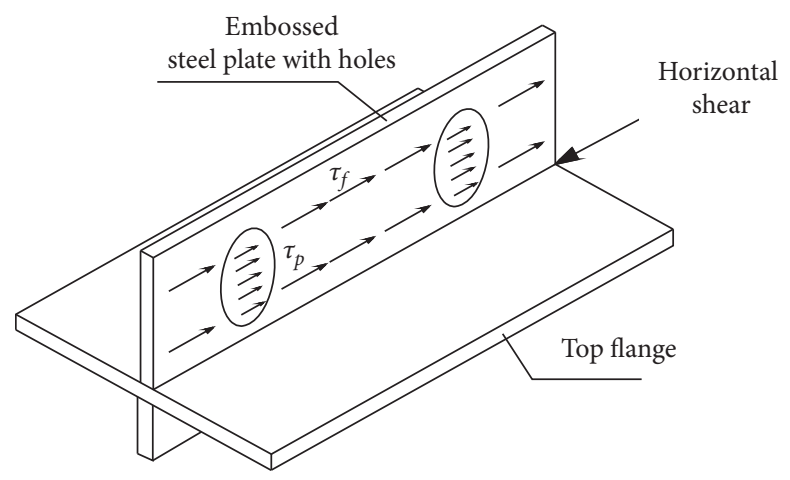

Figure 3: Mechanisms of shear resistance of the adhesive connection.

the shear stiffness of the interface. For the interface between ultrahigh performance concrete (UHPC) and highstrength concrete (HSC), the adhesion value between UHPC and HSC was identified by Hussein et al. [10] through the direct tension test. Meanwhile, Hussein et al. [11] developed a three-dimensional finite-element model to study the UHPC-HSC interface using traction-separation, damage initiation criteria, and damage evolution. In the 
current study, a new generation of adhesive connections is developed using UHPC grout to replace traditional cementitious grouts. Although many experimental tests have already been carried out on embossed steel-to-concrete interfaces and concrete-to-concrete interfaces, almost no work has been conducted on the interface between embossed steel and UHPC grout.

\section{Objectives}

This study aims to provide a new generation of the adhesive connection, referred to as the "enhanced UHPC-grout shear connection." The primary improvement is the use of UHPC as the connection grout. Compared to traditional cementitious grouts, UHPC has good dimensional stability, exceptional durability, and mechanical properties [12]. UHPC has been successfully used in composite connections between precast bridge decks and steel girders [13-17]. It is expected that the advanced properties of UHPC allow for a significant improvement of the ductility, ultimate capacity, and durability of the adhesive connection. First, grouting tests are conducted to compare the constructability and compactness of different grouting methods. Second, pushout tests of shear connectors are performed to study the shear resistance performance of the new connection. Then, the finite-element approach is used to simulate the behavior of the new connection. Finally, design recommendations are provided for practical application.

\section{Comparison of Two Grouting Methods for UHPC}

3.1. UHPC Mixture and Properties. The UHPC used in this study is a commercially available product in China. Table 1 shows the composition of this material. The UHPC is composed of Portland cement, fine sand, silica fume, high active admixture, superplasticizer, steel fibers, and water. The maximum particle size of quartz sand was $0.6 \mathrm{~mm}$. Straight steel fibers coated with a thin layer of copper were used, and a fiber volume fraction of $1.5 \%$ was adopted in the test. The steel fibers had a diameter of $0.2 \mathrm{~mm}$ and a length of $13 \mathrm{~mm}$. The ultimate tensile strength of the steel fibers was $2000 \mathrm{MPa}$. The steel fibers have a length of $13 \mathrm{~mm}$, a diameter of $0.2 \mathrm{~mm}$, and tensile strength of $2000 \mathrm{MPa}$.

The mechanical properties of UHPC were determined according to GB 50010-2010 [18]. Cubic specimens $(150 \mathrm{~mm} \times$ $150 \mathrm{~mm} \times 150 \mathrm{~mm}), \operatorname{dog}$ bone specimens $(100 \mathrm{~mm} \times 100 \mathrm{~mm} \times$ $500 \mathrm{~mm})$, and prism specimens $(100 \mathrm{~mm} \times 100 \mathrm{~mm} \times 300 \mathrm{~mm})$ were used to measure the compressive strength, the direct tensile strength, and the elasticity modulus, respectively. After 28 days of curing, the averaged mechanical properties of UHPC are measured as follows: cube compressive strength $f_{c}=$ 125.6 MP, direct tensile strength $f_{t}=6.8 \mathrm{MPa}$, and elasticity modulus $E_{c}=49 \mathrm{GPa}$.

3.2. Test Setup for Grouting. The grouting of UHPC into the channel void of the connection may be realized by two methods: (1) pressure grouting from the channel end; (2) self-levelling grouting from the top pockets. To compare the constructability and compactness of two grouting methods (Figure 4), three specimens were fabricated to simulate the grouting channel, including one for pressure grouting from the channel end and two for self-levelling grouting from top pockets.

Figure 5 shows the test setup for the pressure grouting from the channel end. The length of the model is $5000 \mathrm{~mm}$. The steel plate in the center of the model is used to simulate the steel rib interface in the actual connection, and the acrylic sheets are used to simulate the concrete interface. The applied maximum grouting pressure is $2 \mathrm{MPa}$.

Figure 6 shows the test setup for the self-levelling grouting from top pockets. Two models with the same length $(3000 \mathrm{~mm})$ and different spacing of grouting pockets $(1000 \mathrm{~mm}$ and $1400 \mathrm{~mm})$ were fabricated. The size of the grouting pockets is $80 \mathrm{~mm} \times 80 \mathrm{~mm}$, and the diameter of the vent hole is $10 \mathrm{~mm}$.

3.3. Results of Grouting Tests. The grout quality using the pressure method is shown in Figure 7. As can be seen, defects appeared in the locations of inlets and outlets. Meanwhile, a large area of crystalline bloom was observed on the interfaces. The grout quality using the self-levelling method is shown in Figure 8. Specimen SL-1 had three grouting pockets. The UHPC grout was injected first from the side pockets and then from the middle pocket. Specimen SL-2 had two grouting pockets and was grouted from them simultaneously. As can be seen, Specimen SL-1 exhibited honeycombing, while Specimen SL-2 had no apparent defects. It can be concluded that self-levelling grouting is better than pressure grouting, in terms of the convenience in construction and grout quality.

\section{Push-Out Testing of Shear Connectors}

4.1. Specimen Design and Fabrication. Two sets of push-out testing of adhesive connectors were conducted, including three specimens with the HMP grout and seven specimens with the UHPC grout. The parameters of the specimens are listed in Table 2. Among the ten specimens, five specimens had circular holes in the embossed steel rib to generate the dowel effect.

All push-out specimens have the same outside dimensions, as shown in Figure 9. The dimensions of the concrete block (length $\times$ width $\times$ height) are $670 \mathrm{~mm} \times 500 \mathrm{~mm} \times$ $600 \mathrm{~mm}$. The thickness of the embossed steel rib is $12 \mathrm{~mm}$, and the height is $115 \mathrm{~mm}$. The embossed steel plate was roughed by $2 \mathrm{~mm}$ deep grooves. The size of the slot performing in the concrete block is $60 \mathrm{~mm} \times 120 \mathrm{~mm}$. The surface of the slot was roughened by sand-blasting.

Figure 10 shows the fabrication of the push-out test specimens. After applying roughness treatment to the steel rib and the concrete slot, they were assembled together, and then the void was injected with HPM or UHPC grouts.

4.2. Test Setup and Instruments. Figure 11 shows the setup of the push-out testing. Dial gauges were used to measure the slip and the uplift. Slip measurements were taken on both 
TABLE 1: Relative weight ratios to cement in the mix design.

\begin{tabular}{lcccccc}
\hline Cement & Fine sand & Silica fume & Highly active admixture & Superplasticizer & Steel fiber & Water \\
\hline 1.0 & 1.1 & 0.25 & 0.28 & 0.05 & 0.22 & 0.2 \\
\hline
\end{tabular}

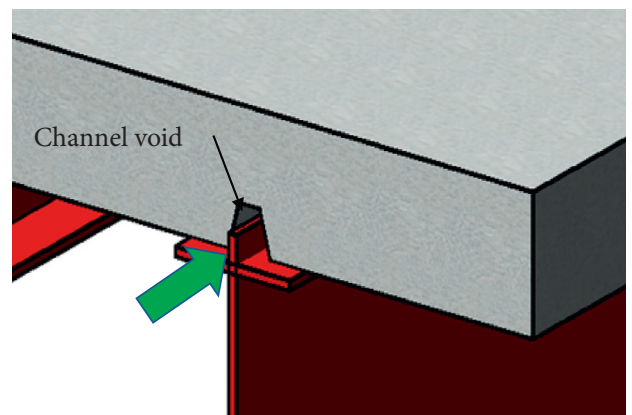

(a)

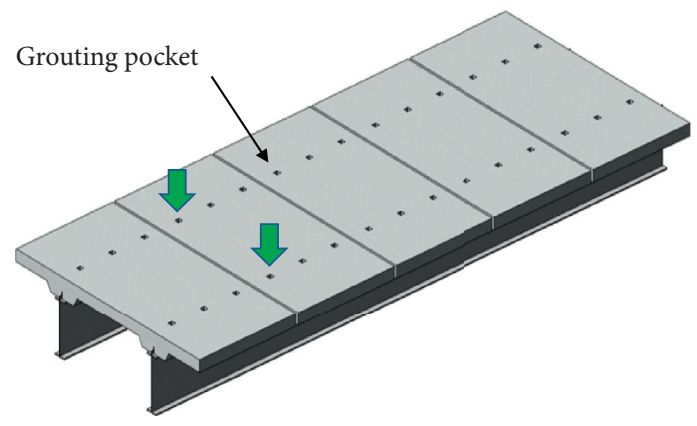

(b)

FIGURE 4: Two grouting methods: (a) pressure grouting; (b) self-levelling grouting.

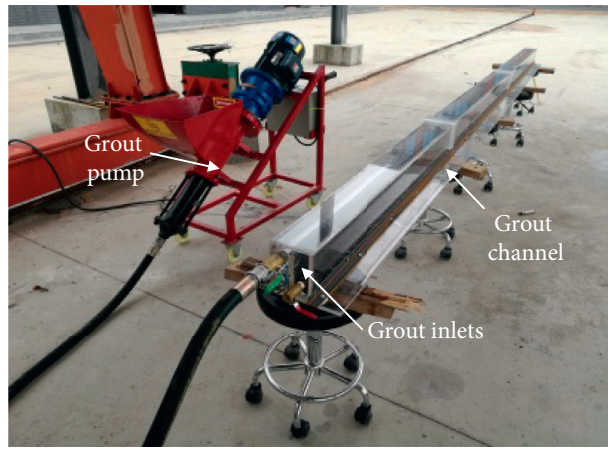

(a)

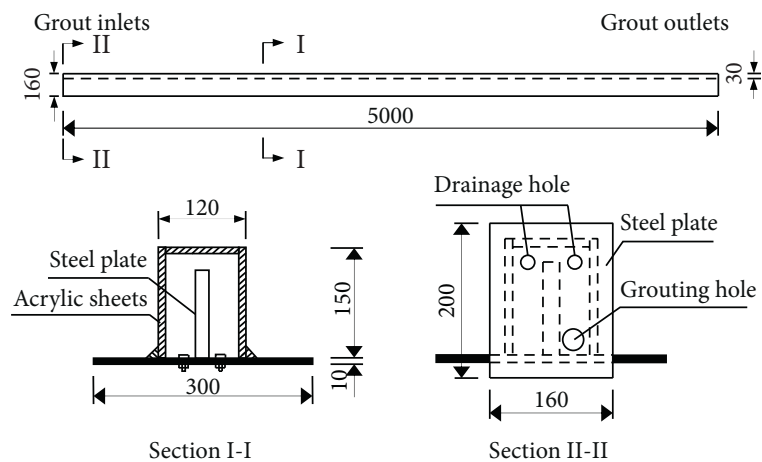

(b)

FIGURE 5: Test setup for pressure grouting from the channel end (dimensions in $\mathrm{mm}$ ).

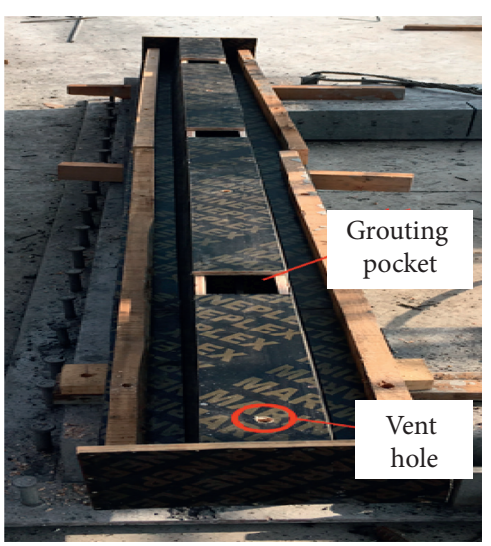

(a)

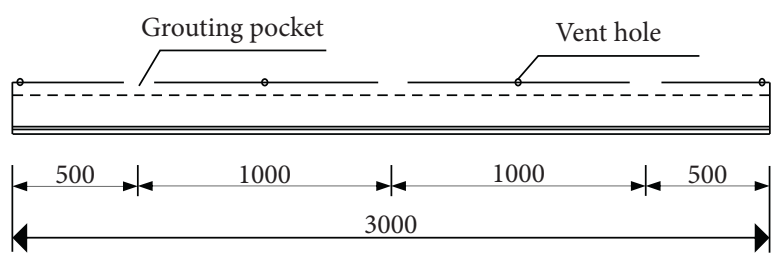

$\underline{\text { SL-1 }}$

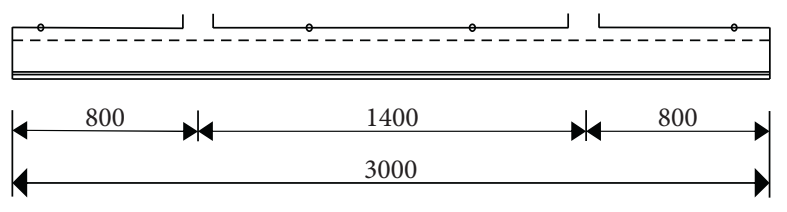

$\underline{\mathrm{SL}-2}$

(b)

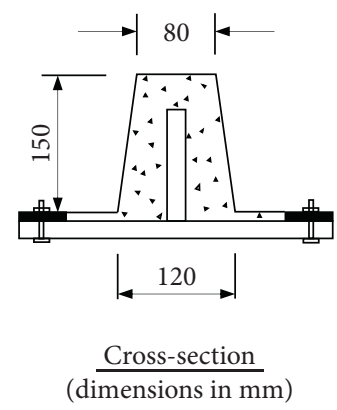

(c)

FIgURE 6: Test setup for self-levelling grouting from the top pockets. 


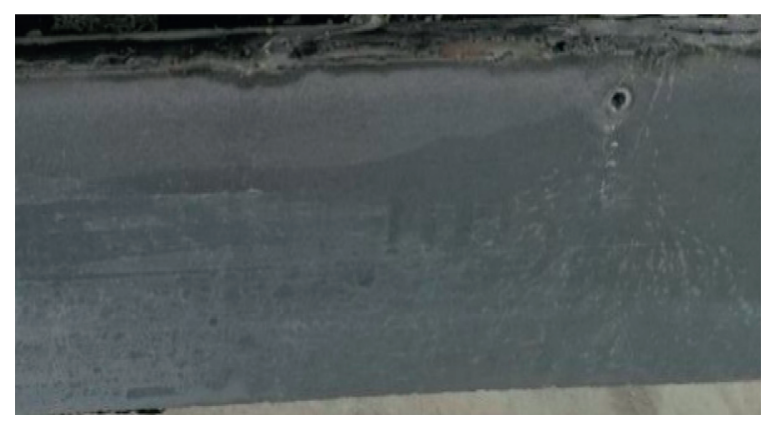

(a)

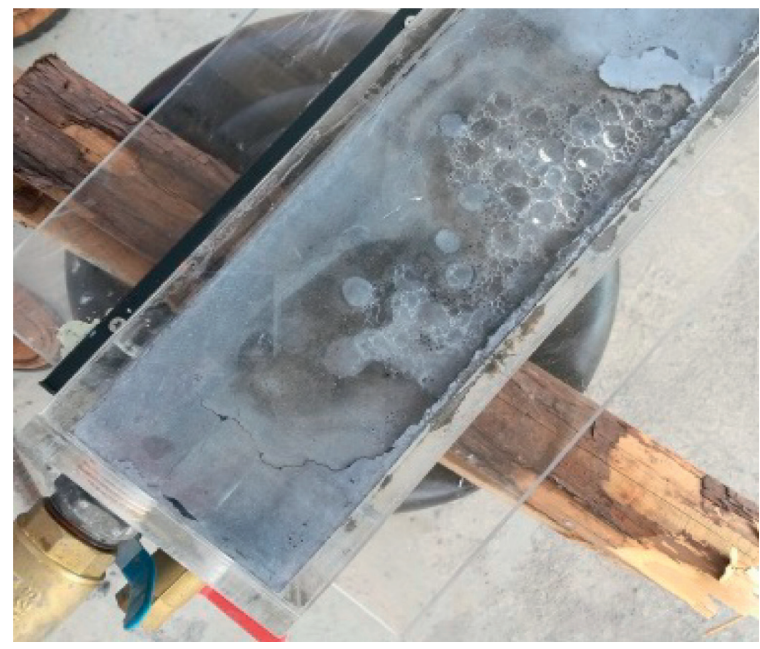

(c)

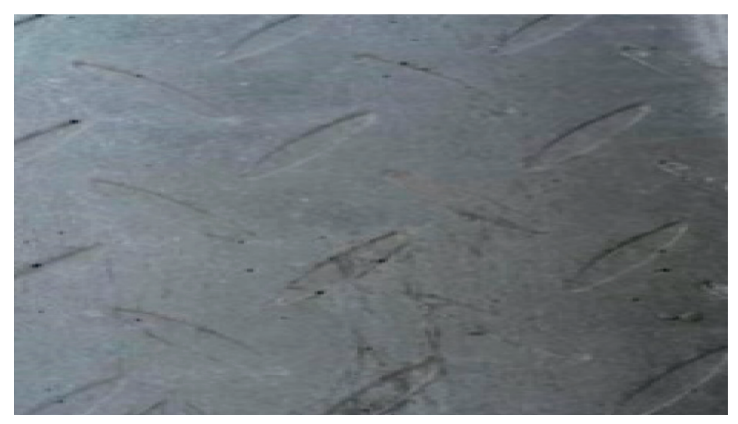

(b)

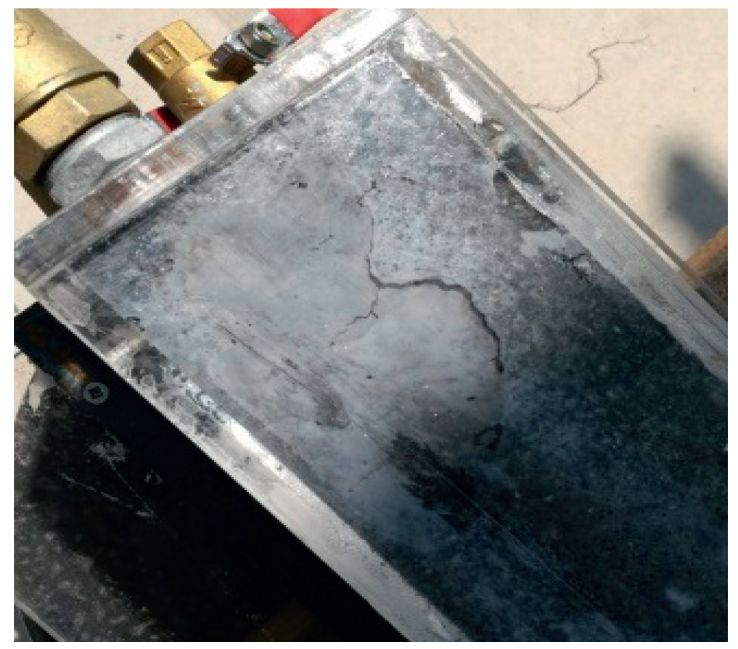

(d)

FIGURE 7: Inspection of quality of pressure grouting. (a) Interface of acrylic sheet. (b) Interface of steel plate. (c) Grout inlets. (d) Grout outlets.
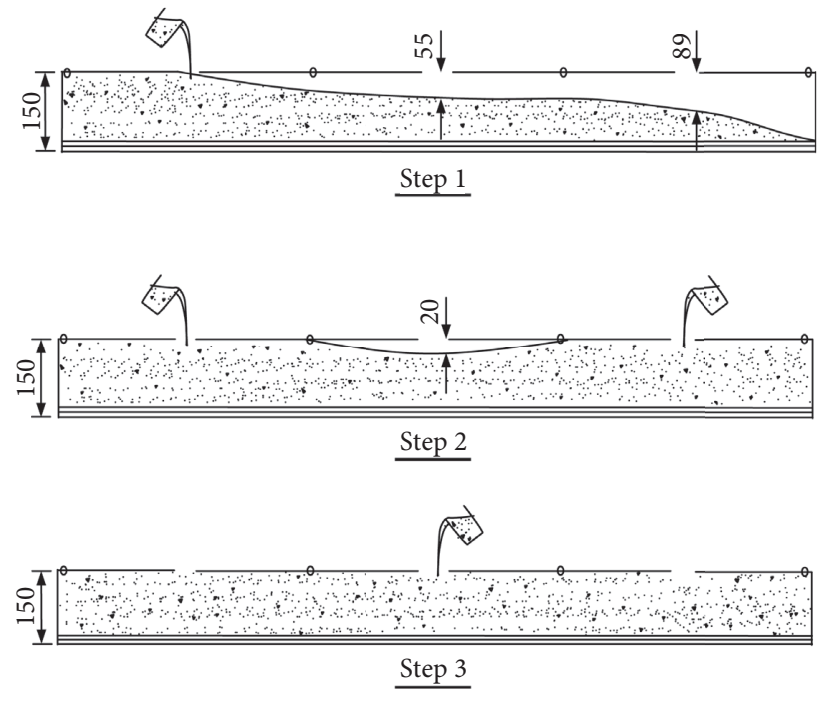

(a)

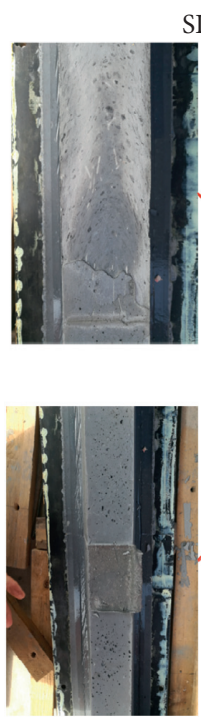

SL-1

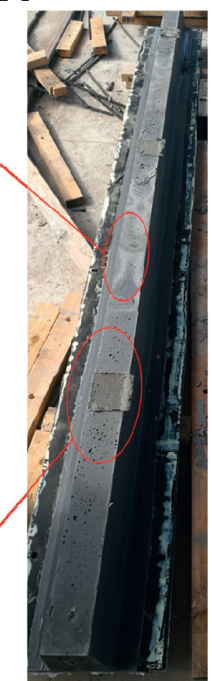

(b)

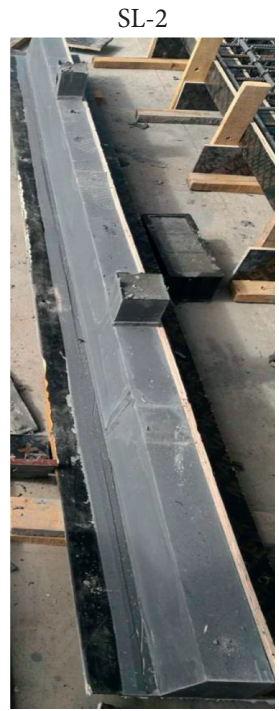

FIGURE 8: Self-levelling grouting: (a) grouting process; (b) grouting quality. 
TABLE 2: Parameters of adhesive shear connectors.

\begin{tabular}{lccc}
\hline Specimen & Grout material & Compressive strength of grout (MPa) & Holes in steel rib \\
\hline HPM-1 & HPM & 72 & w/o \\
HPM-2-H & HPM & 72 & w/ \\
HPM-3-H & HPM & 72 & w/ \\
UHPC-1 & UHPC & 120 & w/o \\
UHPC-2 & UHPC & 120 & w/o \\
UHPC-3 & UHPC & 125 & w/o \\
UHPC-4 & UHPC & 125 & w/o \\
UHPC-5-H & UHPC & 125 & w/ \\
UHPC-6-H & UHPC & 115 & w/ \\
UHPC-7-H & UHPC & 115 & w/ \\
\hline
\end{tabular}
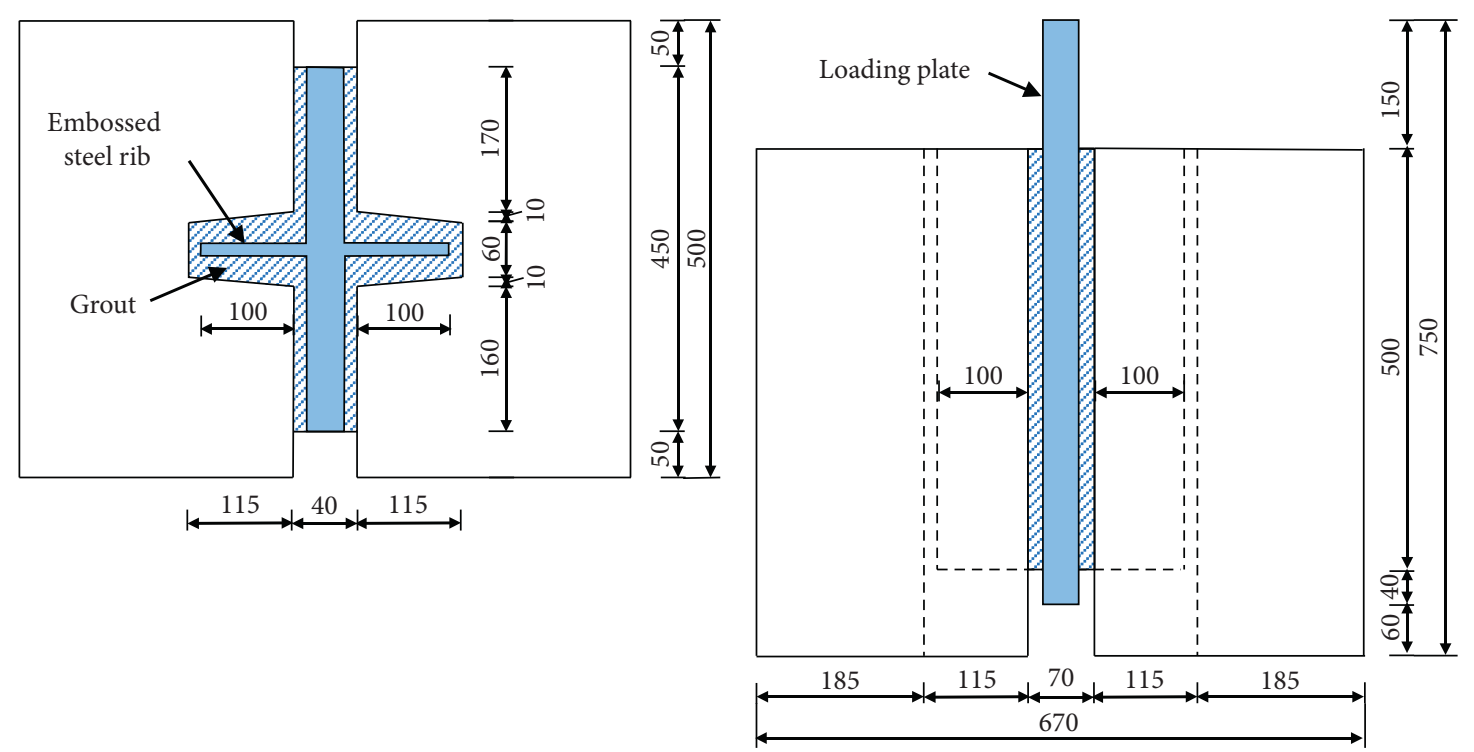

(a)

(b)
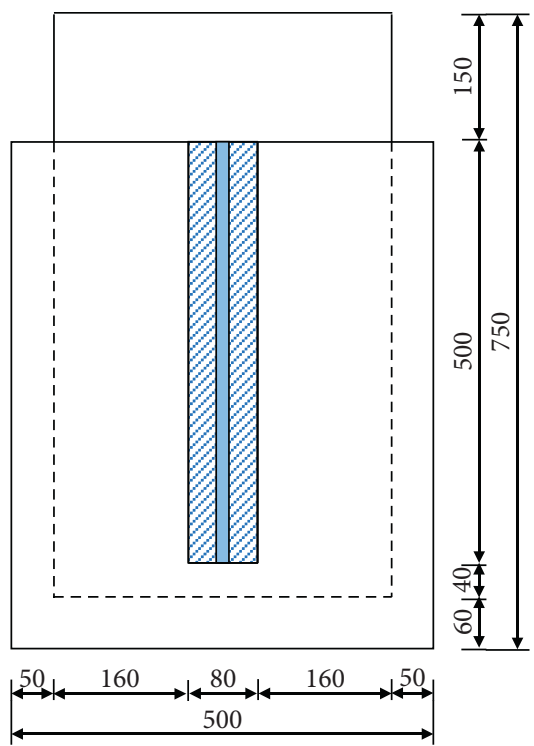

(c)

Figure 9: Geometry of push-out test specimens (dimensions in mm). (a) Plan view. (b) Front view. (c) Side view. 


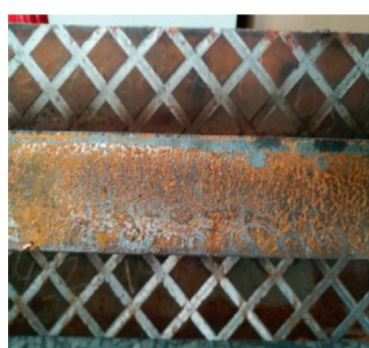

Embossed steel rib

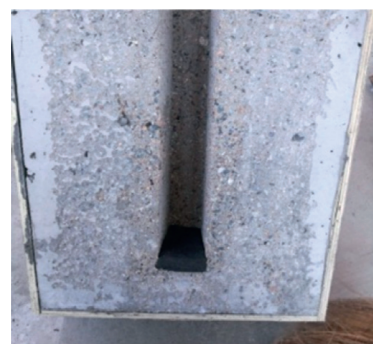

Concrete block

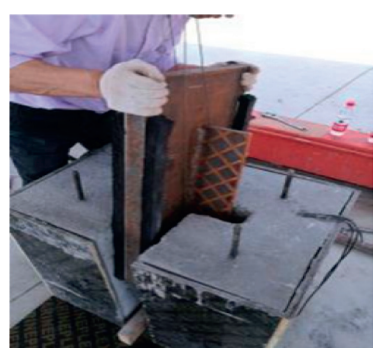

Assemble

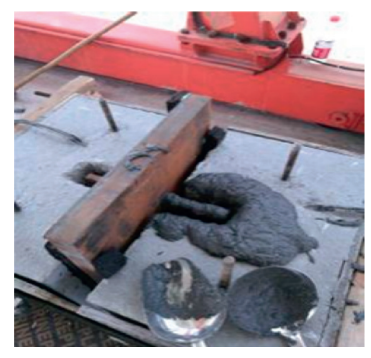

Grouting

Figure 10: Fabrication of push-out test specimens.
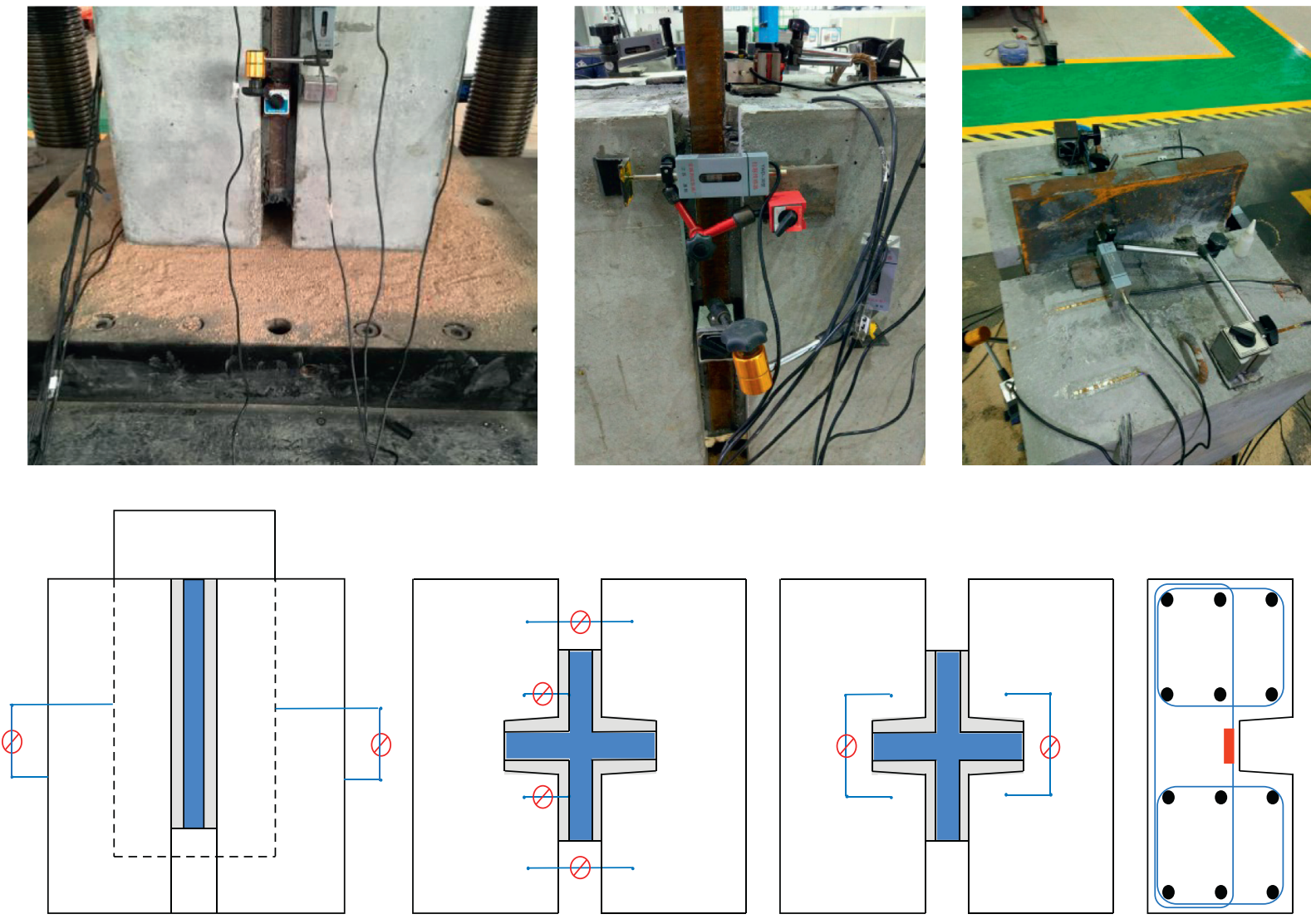

๑ Displacement gauges

Strain gauges

Figure 11: Test setup and instruments.

sides of the specimens, at half of its height. Uplift measurements were taken in both top and bottom faces. The maximum range of the dial gauge was $15 \mathrm{~mm}$, far beyond the ultimate slip and uplift.

The specimens were first loaded under force control. The loading procedure was $0 \mathrm{kN} \longrightarrow 50 \mathrm{kN} \longrightarrow 0 \mathrm{kN} \longrightarrow$ $200 \mathrm{kN} \longrightarrow 400 \mathrm{kN} \longrightarrow 600 \mathrm{kN}$. Afterward, the force control was replaced with displacement control, with a loading speed of $0.005 \mathrm{~mm} / \mathrm{s}$ until the maximum loading capacity was reached. Afterward, a loading speed of $0.015 \mathrm{~mm} / \mathrm{s}$ was imposed until failure.

\section{Test Results and Discussion}

5.1. Failure Modes. The failure mode of push-out specimens is affected by many parameters. According to the previous study of Papastergiou and Lebet [5], two typical failure modes were observed on the embossed steel-grout interface. For the mode of bearing failure, the failure surface is mainly located at the steel-grout interface, with only a small amount of grout residue behind the steel ribs. For the mode of shear failure, the failure surface locates entirely in the grout paste. 
In this study, all specimens failed along the embossed steel-grout interface, exhibiting a typical mode of shear failure (Figure 12). At the initial stage of loading, no apparent interface slip was observed. With the increase of loading, diagonal cracks were observed in the corner of grouting channels on the top face (Figure 12(a)). Prior to the ultimate failure, sound induced by the splitting of grout material was recorded. Finally, grout crushing was observed on the bottom face of the specimen (Figure 12(b)).

5.2. Interface Shear Mechanism. Figure 13 illustrates the interface between embossed steel and grout subjected to horizontal shear and transversal compression. The interface tends to slip ( $s$ ) due to the development of the longitudinal shear stress $(\tau)$. Due to the roughness of the interface, this slip is accompanied by a separation of materials, called uplift $(u)$ at a direction normal to the slip. This uplift is however restrained due to the confinement normal stress $(\sigma)$ created by the surrounding concrete slab. Therefore, the interface is subjected to a combination of horizontal shear and transversal confinement. The previous study by Thomann and Lebet [4] found that the shear-slip curve $(\tau-s)$, the slip-uplift curve $(s-u)$, and the slip-normal stress curve $(s-\sigma)$ are critical in describing the mechanical behavior of the adhesive connection.

5.3. Shear-Slip Behavior. The shear-slip curves of all specimens are shown in Figure 14. The stiffness of the adhesive connection was very high in the elastic stage. The maximum shear strength was achieved with slippage of approximately $1 \mathrm{~mm}$. The residual shear strength was about one-half of the maximum shear strength. The ultimate slippage was about $8 \mathrm{~mm}$ for most specimens.

5.4. Slip-Uplift Behavior. The uplift $(u)$, which reflects the dilatancy of connections, is the transverse separation between the concrete block and the shear connector. Figure 15 shows the slip-uplift $(s-u)$ curves for eight specimens with recorded data. The uplift increased rapidly toward a maximum value. The uplift of the connections with UHPC grout is much smaller than those with HPM.

5.5. Slip-Normal Stress Behavior. Due to the restraint of surrounding concrete slabs, the uplift cannot be released completely. Hence, the normal stress is created by the confinement effect. Figure 16 shows the slip-normal stress $(s-\sigma)$ curves for two specimens with recorded data. The maximum confinement normal stress was about $3 \mathrm{MPa}$, and the residual confinement normal stress was about $1.5 \mathrm{MPa}$.

5.6. Comparative Analysis. From the comparative analysis of the test data listed in Table 3, the following conclusions can be drawn:

(1) The presence of holes in the steel rib can significantly increase the shear resistance of the adhesive connection [19]
(2) Compared with the HPM grout, the utilization of UHPC grout can significantly increase the shear resistance of the adhesive connection by approximately $50 \%$

(3) The uplift of the connections with UHPC grout is much smaller than those with HPM

\section{Finite-Element (FE) Analysis}

6.1. FE Models. In the present study, all FE analyses were performed using the commercial software package ANSYS (Release 10.0). Figure 17 shows the three-dimensional FE model of the push-out specimens. In the model, the concrete block and the UHPC grout were modelled by eight-node solid elements (SOLID65), and the steel rib was simulated by four-node shell elements (SHELL43). The connection between the interfaces was simulated by contact elements (CONTA174).

In the push-out testing of this study, the failure of the specimens was controlled by the interface shear failure, while no apparent damage was observed in the concrete block and the UHPC grout. For this reason, the concrete block, the UHPC grout, and the steel plate were treated as elastic materials in the FE analysis. The moduli of elasticity of normal-strength concrete, UHPC, and steel were taken as $30 \mathrm{GPa}, 49 \mathrm{GPa}$, and $200 \mathrm{GPa}$, respectively. Poisson's ratios of normal-strength concrete, UHPC, and steel were set to be $0.2,0.2$, and 0.3 , respectively.

6.2. Constitutive Laws of Interfaces. According to the fib Model Code [20], in monotonic loading, the relationship between shear stress and slip for interfaces in adhesive connections can be described as follows (Figure 18(a)):

$$
\tau= \begin{cases}\tau_{u}\left(s / s_{1}\right), & 0 \leq s \leq s_{1}, \\ \frac{\tau_{u}-\left(\tau_{u}-\tau_{r}\right)\left(s-s_{1}\right)}{\left(s_{2}-s_{1}\right)}, & s_{1} \leq s \leq s_{2}, \\ \tau_{r}, & s>s_{2},\end{cases}
$$

where $\tau_{u}$ is ultimate shear stress; $\tau_{r}$ is residual shear stress; $s_{1}$ is slip corresponding to ultimate shear stress; $s_{2}$ is slip corresponding to residual shear stress.

The parameters in the constitutive law of equation (1) were determined based on the experimental results of Papastergiou and Lebet [5], who conducted a series of direct shear tests on confined interfaces. As shown in Figure 18(b), the $\tau$-s curves of the embossed steel-grout interface under different confinement normal stresses are presented. In the tests of this study, the maximum confinement normal stress was measured as approximately $3 \mathrm{MPa}$. The $\tau$-s curve at the level of $\sigma=3 \mathrm{MPa}$ is transferred to the trilinear model in equation (1). Similarly, Figure 18(c) shows the $\tau$-s curves of the rough concrete-grout interface. The parameters in constitutive laws of two interfaces are listed in Table 4. 


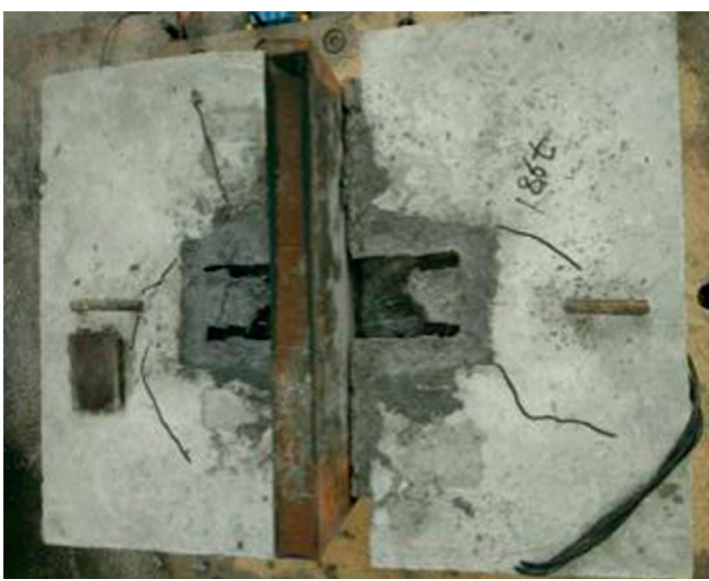

(a)

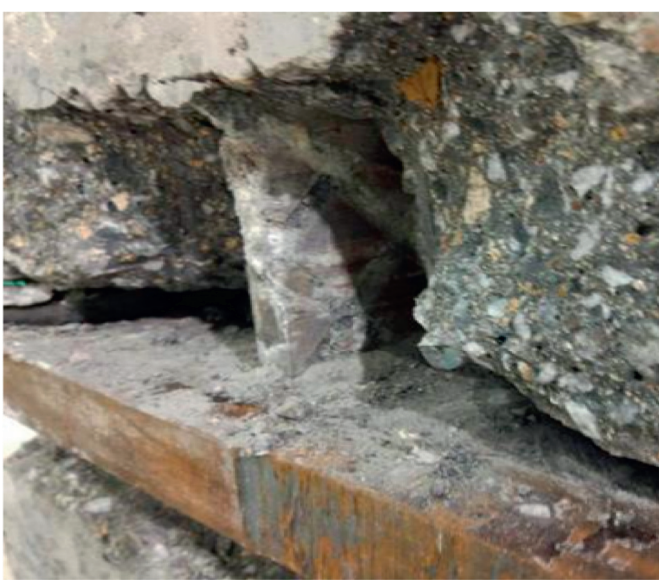

(b)

FIGURE 12: Typical failure mode of push-out test specimens: (a) top face; (b) bottom face.

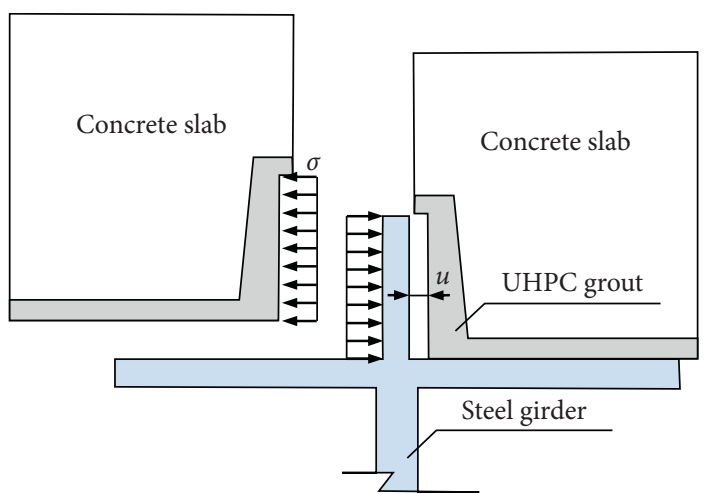

(a)

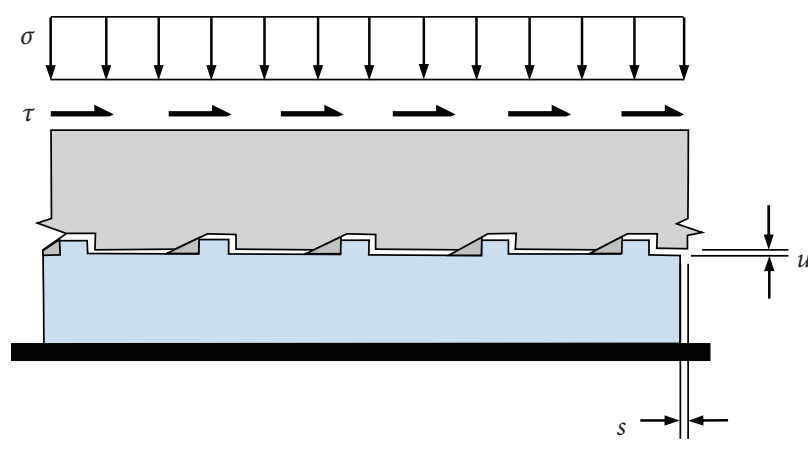

(b)

Figure 13: Development of confinement due to uplift.

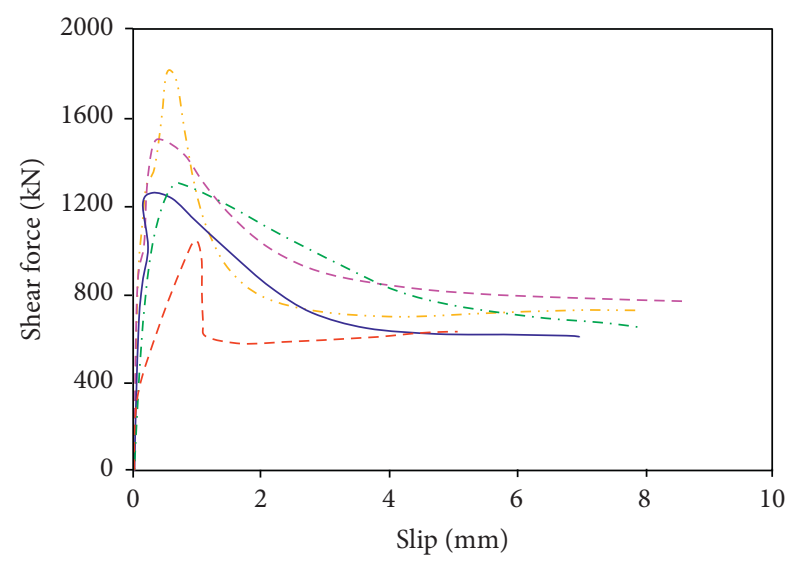

$\begin{array}{ll}\text { _ } & \text { UHPC-1 } \\ \text {-. - } & \text { UHPC-2 } \\ \text { - - - } & \text { UHPC-3 }\end{array}$

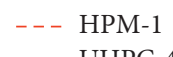

UHPC-4

(a)

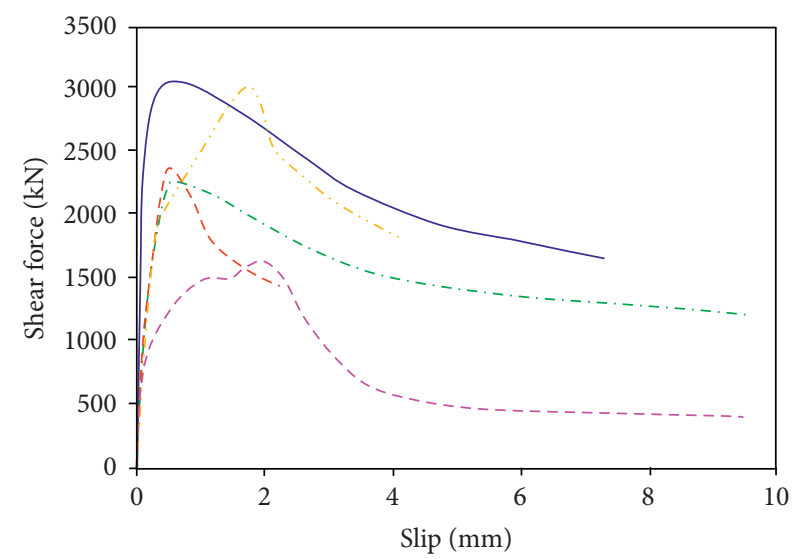

$\begin{array}{lll}\text { - UHPC-5-H } & --- \text { UHPC-6-H } \\ -- \text { HPM-2-H } & \cdots & \text { UHPC-7-H }\end{array}$

- - HPM-3-H

(b)

FIGURE 14: Shear-slip curves: (a) specimens without holes in steel rib; (b) specimens with holes in steel rib. 


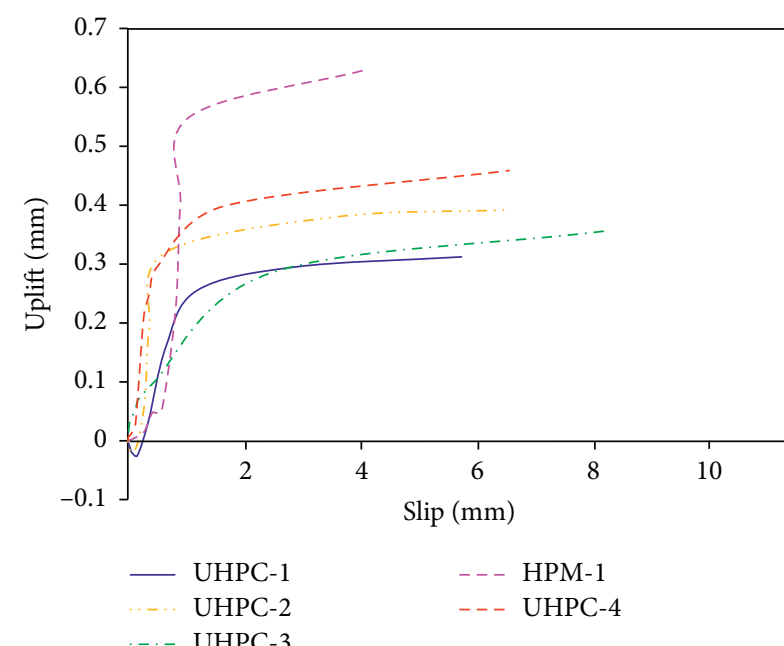

(a)

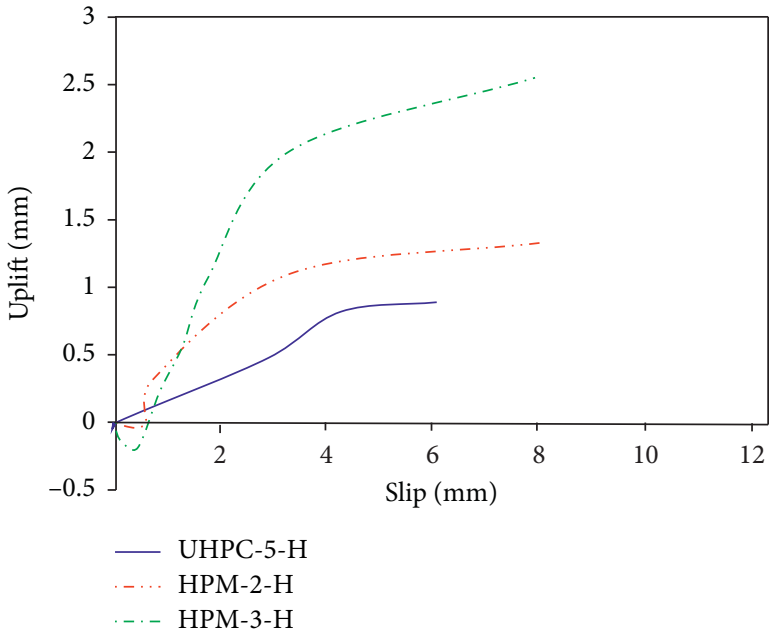

(b)

Figure 15: Slip-uplift curves: (a) specimens without holes in steel rib; (b) specimens with holes in steel rib.

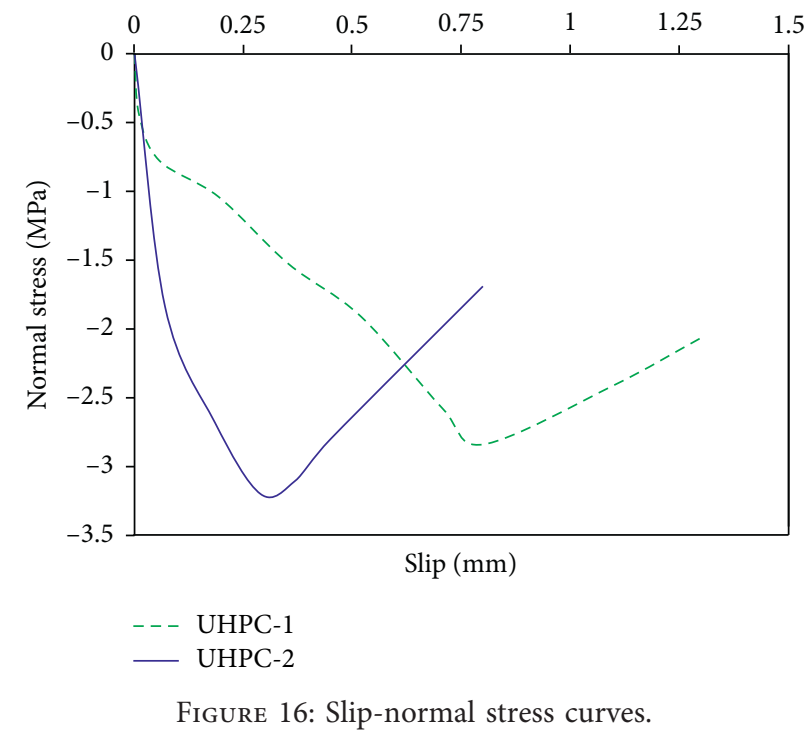

TABLE 3: Ultimate shear capacity of push-out test specimens.

\begin{tabular}{lcr}
\hline Group & Specimen & Ultimate shear capacity (kN) \\
\hline & UHPC-1 & 1280 \\
Specimens without holes in steel rib & UHPC-2 & 1300 \\
& UHPC-3 & 1500 \\
& HPM-1 & 1050 \\
& UHPC-4 & 3050 \\
Specimens with holes in steel rib & UHPC-5-H & 2250 \\
& HPM-2-H & 1600 \\
& HPM-3-H & 2360 \\
\end{tabular}




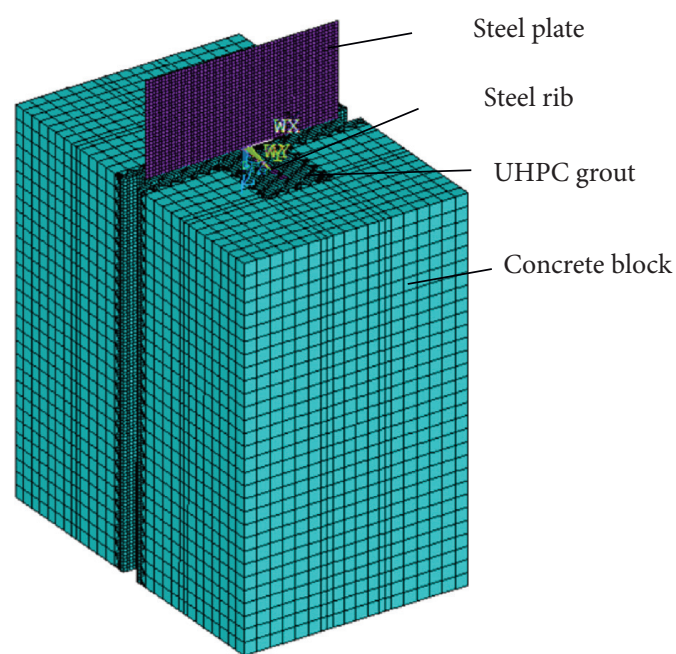

(a)

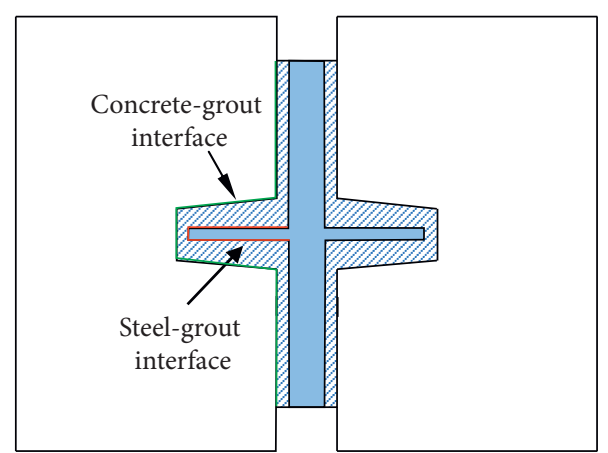

(b)

Figure 17: FE model of push-out test specimen. (a) 3D view. (b) Plane view.
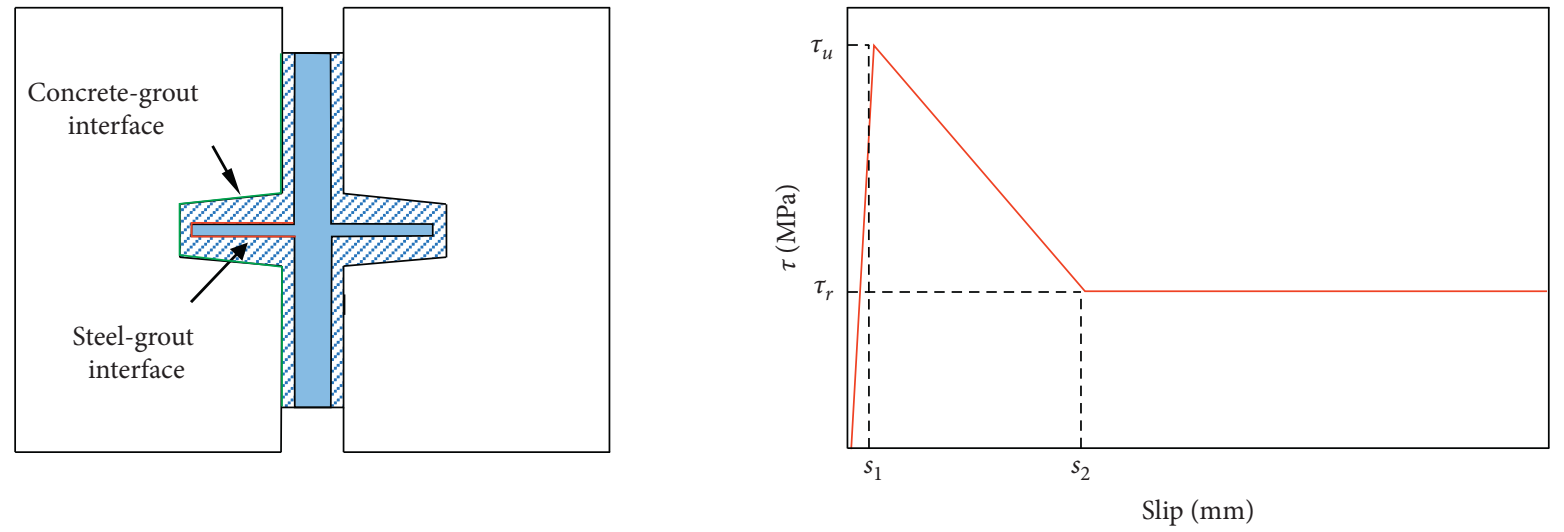

(a)
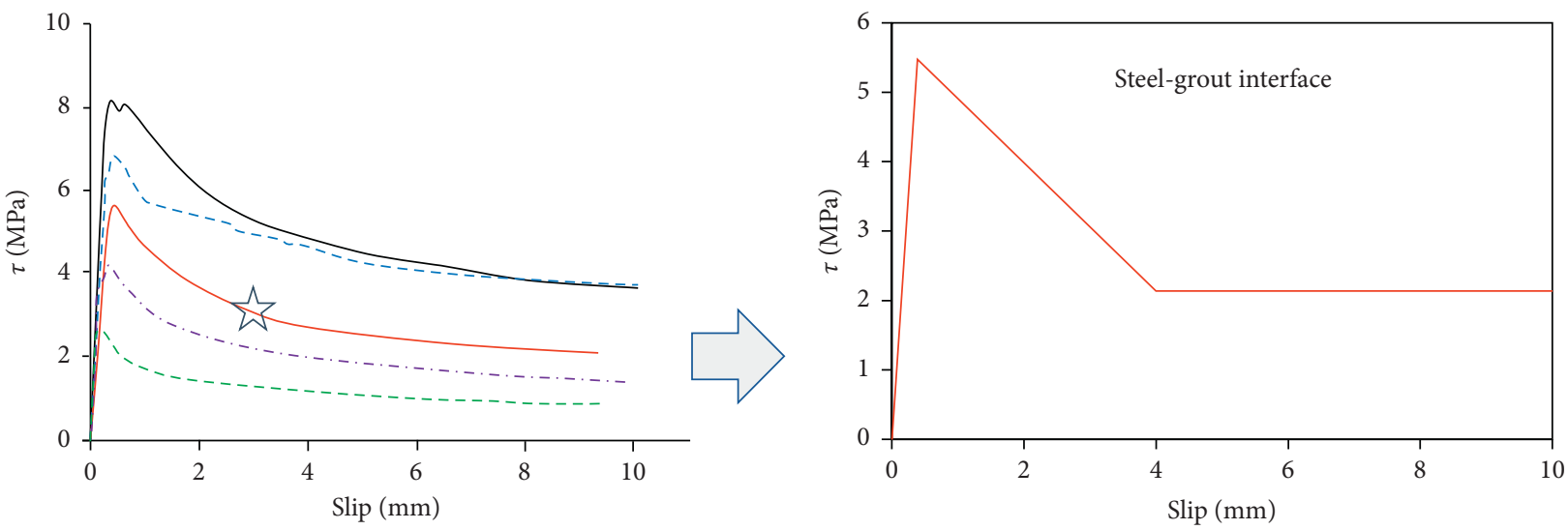
$---\sigma=1$
$---\sigma=4$
-. - $\sigma=2$
$-\sigma=5$
$\sigma=3$

(b)

Figure 18: Continued. 

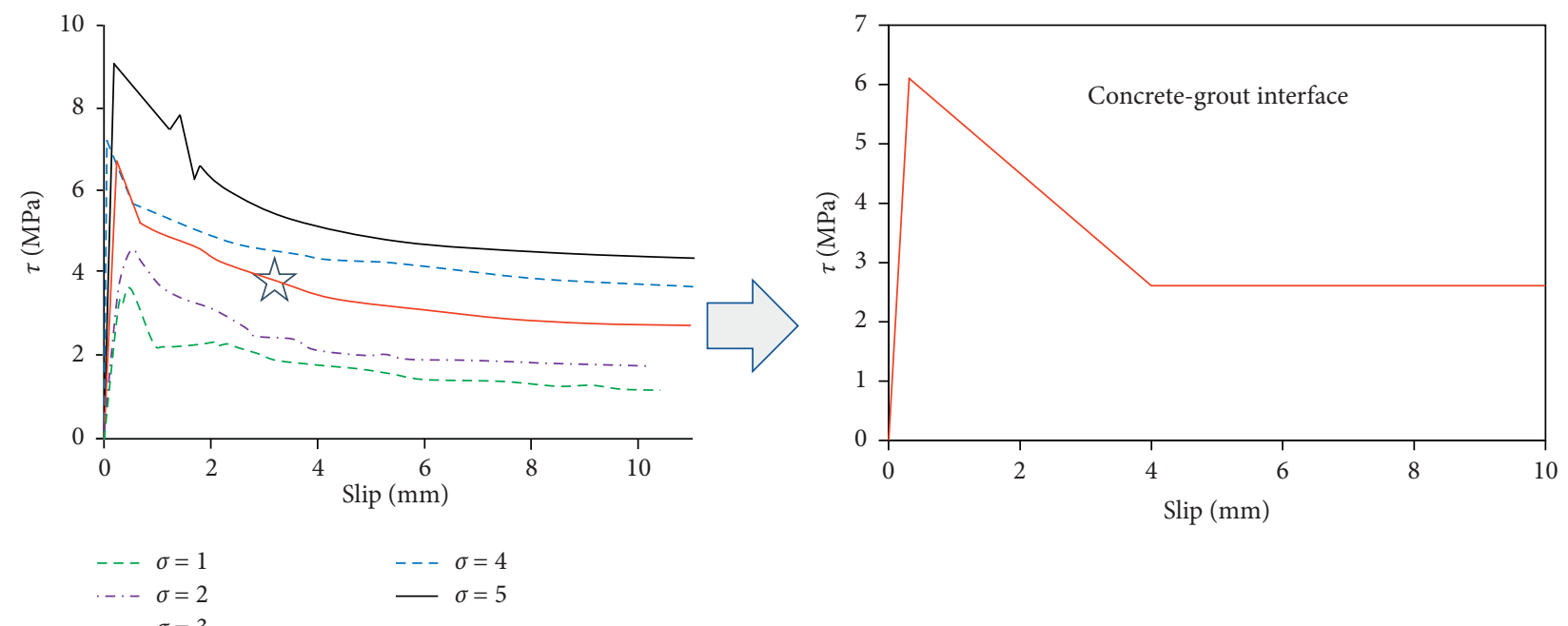

(c)

FIgURE 18: Constitutive laws of interfaces: (a) basic law; (b) steel-grout interface; and (c) concrete-grout interface.

TABLE 4: Parameters in constitutive laws of two interfaces.

\begin{tabular}{lcccc}
\hline Interface & $\tau_{u}(\mathrm{MPa})$ & $\tau_{r}(\mathrm{MPa})$ & $s_{1}(\mathrm{~mm})$ & 0.39 \\
\hline Embossed steel-grout interface & 5.5 & 2.1 & $s_{2}(\mathrm{~mm})$ \\
Rough concrete-grout interface & 6.1 & 2.6 & 0.31 & 4.00 \\
\hline
\end{tabular}

6.3. FE Results. The shear-slip curves obtained from the FE analysis are plotted in Figure 19 to compare with the experimental curves. As can be seen, the FE modelling is capable of capturing the behavior of the UHPC-grout shear connection throughout the whole loading stage. The maximum shear strength and residual shear strength can be well predicted by the FE modelling.

The maximum stresses in the steel plate and the concrete block are shown in Figure 20. As can be seen, a maximum Mises stress of $90 \mathrm{MPa}$ is observed in the upper corner of the steel plate. A maximum principal compressive stress of $36 \mathrm{MPa}$ occurs at the bottom of the concrete block. The results indicate that the steel plate and the concrete block are in the elastic stage. It is reasonable to treat them as elastic materials in the FE analysis.

6.4. Parametric Analysis. The height of the embossed steel rib $\left(h_{\text {rib }}\right)$ is a critical parameter in the design of adhesive connection. Figure 21 shows the force-slip curves of the connector with a rib height of $100 \mathrm{~mm}, 120 \mathrm{~mm}$, and $140 \mathrm{~mm}$, respectively. As shown in Figure 22, there is a linear relationship between the rib height and the interface shear capacity. In other words, the shear capacity of the adhesive connection increases proportionally with the rib height.

\section{Recommendations and Discussion}

7.1. Design Recommendations. Based on the test results, the ultimate shear capacity of the adhesive connection is controlled by the interface shear strength between the embossed steel and UHPC grout [21-23]. The longitudinal shear

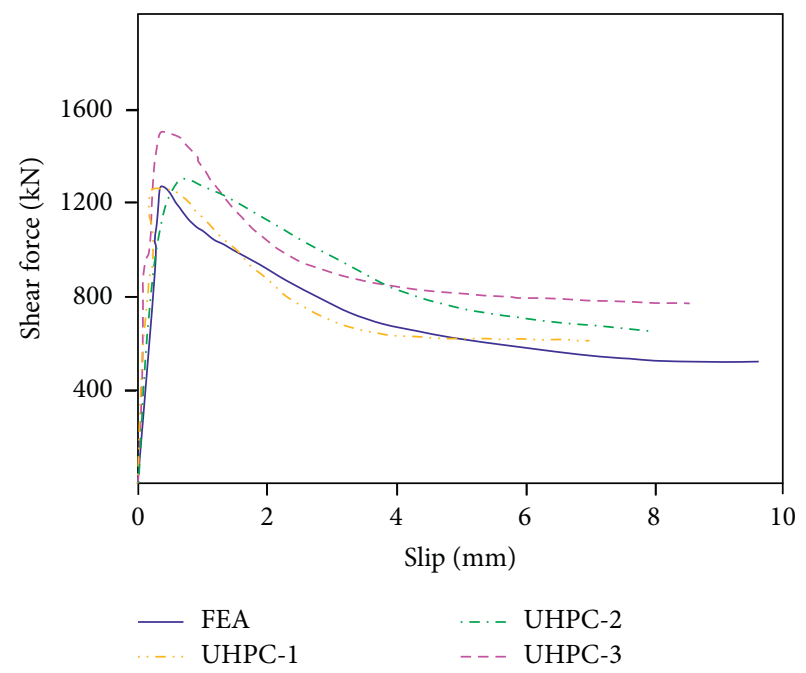

Figure 19: Comparison between numerical load-slip curves and test results.

capacity of the adhesive connection can be expressed as follows:

$$
\overline{V_{u}}=c \cdot h_{\mathrm{rib}},
$$

where $\overline{V_{u}}$ is longitudinal shear capacity per unit length $(\mathrm{kN} /$ $\mathrm{m}) ; c$ is cohesion value $(\mathrm{MPa}) ; h_{\text {rib }}$ is rib height $(\mathrm{mm})$.

Based on regression analysis of the test data, the cohesion value can be taken as $5.87 \mathrm{MPa}$ for the embossed steel-UHPC grout interface. The residual frictional resistance can be taken as approximately one-half of the ultimate resistance. 


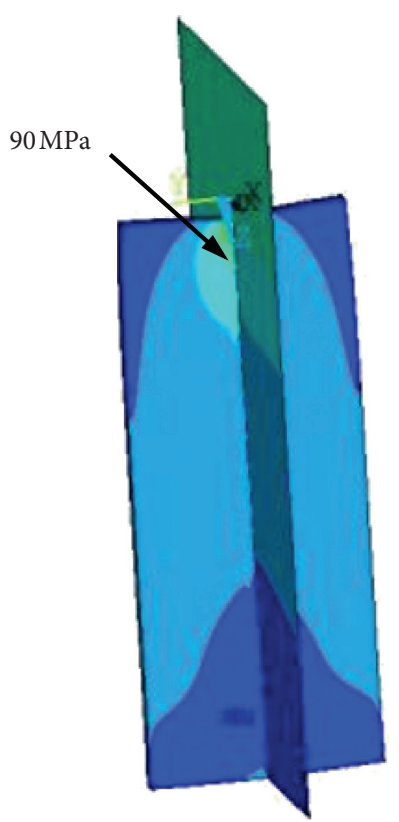

Mises stresses in steel plate

(a)

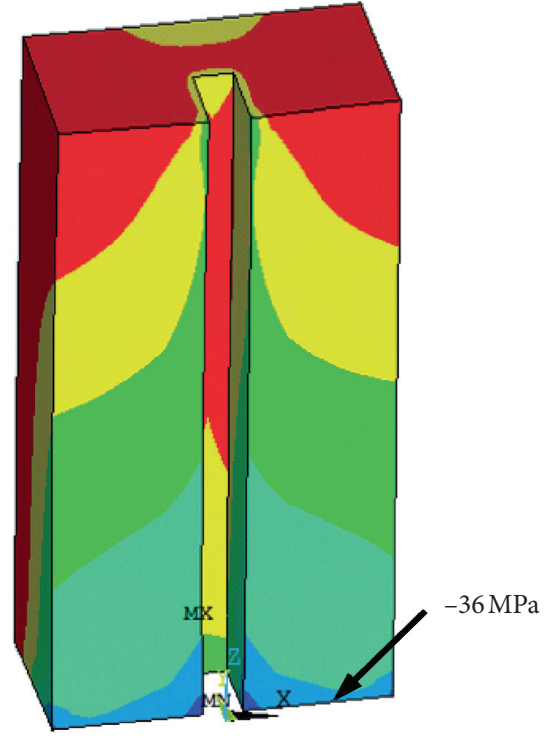

Principal compressive stresses in concrete block

(b)

Figure 20: Maximum stresses in steel plate and concrete block.

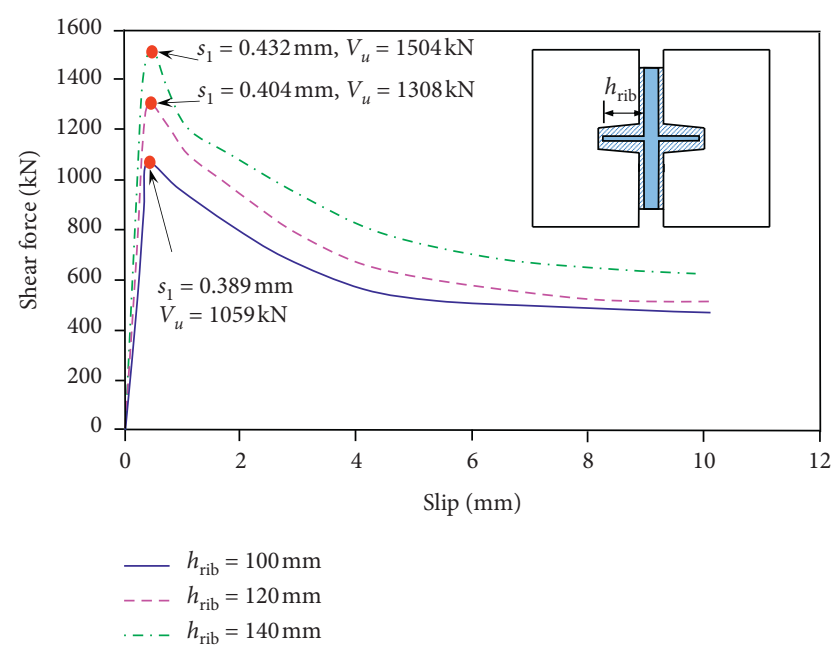

Figure 21: Influence of rib height on interface capacity.

7.2. Discussion. In this study, the experimental tests showed that the UHPC-grout shear connection has the potential to be used in accelerated bridge construction. It is believed that the UHPC-grout shear connection is a promising option for the design of steel-concrete composite bridges. However, more research should be carried out in the following aspects to promote its use in practice:

(1) As pointed out by Diógenes et al. [7], special attention should be given to the fatigue behavior of the connection under vehicular loading and the response under long-term loading.

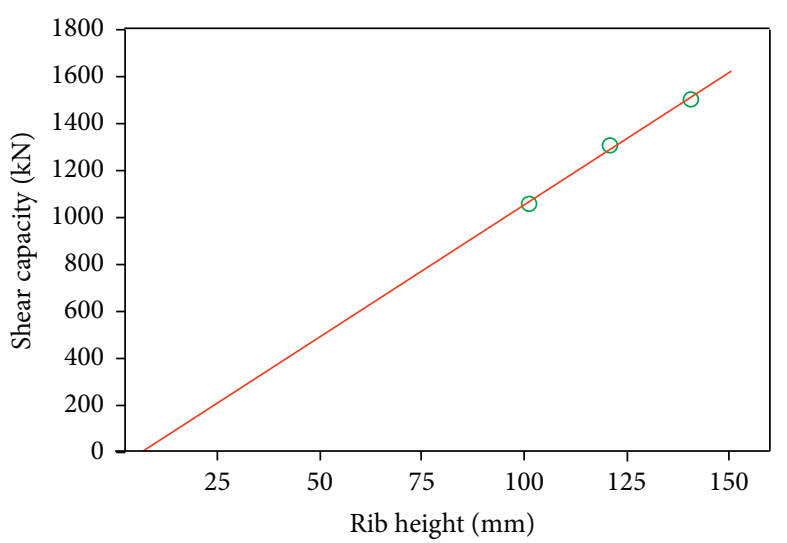

FIGURE 22: Linear relationship between rib height and shear capacity.

(2) Transversal prestressing, which is often applied in the bridge deck, is expected to have a favorable effect on the connection's resistance [3]. This beneficial effect requires further investigation.

(3) The shear connection should resist the horizontal shear force and prevent vertical separation or uplift of the concrete slab from the steel girder. It is necessary to study the uplift effect in the UHPCgrout strip shear connection.

(4) The grouting compactness of UHPC in the channel void of the connection is of vital importance. More research should be conducted to study the 
constructability and compactness of different grouting methods.

\section{Conclusions}

This study aims to provide the third generation of adhesive connection, referred to as the "enhanced UHPC-grout shear connection." The primary improvement is the use of UHPC as the connection grout. Two series of tests were performed to validate the constructability and the mechanical performance of the new connection. The following conclusions can be drawn:

(1) Both the pressure grouting method and the selflevelling grouting method are applicable to inject the UHPC grout into the channel void of the connection. By comparison, self-levelling grouting is better than pressure grouting, in terms of the convenience in construction and grout quality.

(2) The advanced properties of UHPC allow for a significant improvement of the ultimate capacity of the adhesive connection. Compared with the HPM grout, the utilization of UHPC grout can significantly increase the shear resistance of the adhesive connection by approximately 50\%. Meanwhile, the presence of holes in the steel rib can generate a "dowel effect" that significantly increases the shear resistance of the adhesive connection.

(3) The ultimate shear capacity of the adhesive connection is controlled by the interface shear strength between the embossed steel and the UHPC grout, with a cohesion value of approximately $5.87 \mathrm{MPa}$. Meanwhile, the residual frictional resistance can be taken as approximately one-half of the ultimate resistance.

(4) The results of FE analysis show that the trilinear model is reasonable to simulate the constitutive laws of interfaces, and the shear capacity of the adhesive connection increases proportionally with the height of the embossed steel rib.

\section{Data Availability}

The data used to support the findings of this study are available from the corresponding author upon request.

\section{Conflicts of Interest}

The authors declare that there are no conflicts of interest regarding the publication of this paper.

\section{Authors' Contributions}

Zhang $\mathrm{Y}$ and Zheng $\mathrm{H}$ conceived and designed the experiments. Zheng $\mathrm{H}$ and Tang $\mathrm{M}$ performed the experiments and numerical simulation. Zheng $\mathrm{H}$ and $\mathrm{He} \mathrm{Z}$ analyzed the data. Zhang $\mathrm{Y}$, Zheng $\mathrm{H}$, and $\mathrm{He} \mathrm{Z}$ wrote the manuscript.

\section{Acknowledgments}

This work was supported by the Outstanding Youth Foundation of Jiangsu Province, China (no. BK20180063) and the National Natural Science Foundation of China (no. 51778137).

\section{References}

[1] S. S. Badie, A. F. Morgan Girgis, M. K. Tadros, and N. T. Nguyen, "Relaxing the stud spacing limit for full-depth precast concrete deck panels supported on steel girders (phase I)," Journal of Bridge Engineering, vol. 15, no. 5, pp. 482-492, 2010.

[2] Z. Haber, B. Graybeal, and B. Nakashoji, "Ultimate behavior of deck-to-girder composite connection details using UHPC," Journal of Bridge Engineering, vol. 25, no. 7, Article ID 04020038, 2020.

[3] M. Thomann, Connexions par Adhérence Pour les Ponts Mixtes Acier-Béton, Ph. D. thesis, École Polytechnique Fédérale de Lausanne (EPFL), Lausanne, Switzerland, 2005.

[4] M. Thomann and J.-P. Lebet, "The modelling of an embossed steel-to-cement paste confined interface loaded in shear," Journal of Constructional Steel Research, vol. 63, no. 5, pp. 639-646, 2007.

[5] D. Papastergiou and J.-P. Lebet, "Experimental investigation and modelling of the structural behaviour of confined grouted interfaces for a new steel-concrete connection," Engineering Structures, vol. 74, pp. 180-192, 2014.

[6] H. J. F. Diógenes, A. L. H. C. El Debs, and I. B. Valente, "Experimental analysis of new interfaces for connections by adhesion, interlocking and friction," Journal of Constructional Steel Research, vol. 110, pp. 170-181, 2015.

[7] H. J. F. Diógenes, A. L. H. C. El Debs, and I. B. Valente, "Tests on composite beams using new connections by adherence," Proceedings of the Institution of Civil Engineers-Structures and Buildings, vol. 171, no. 2, pp. 149-165, 2018.

[8] G. Minafò, "Analytical modelling of force transmission in axially loaded RC columns with indirectly loaded jackets," Engineering Structures, vol. 181, pp. 15-26, 2019.

[9] G. Campione, M. Fossetti, G. Minafò, and M. Papia, "Influence of steel reinforcements on the behavior of compressed high strength R.C. circular columns," Engineering Structures, vol. 34, no. 1, pp. 371-382, 2012.

[10] H. H. Hussein, K. K. Walsh, S. M. Sargand, and E. P. Steinberg, "Interfacial properties of ultrahigh-performance concrete and high-strength concrete bridge connections," Journal of Materials in Civil Engineering, vol. 28, no. 5, Article ID 04015208, 2016.

[11] H. H. Hussein, K. K. Walsh, S. M. Sargand, F. T. Al Rikabi, and E. P. Steinberg, "Modeling the shear connection in adjacent box-beam bridges with ultrahigh-performance concrete joints. I: model calibration and validation," Journal of Bridge Engineering, vol. 22, no. 8, Article ID 04017043, 2017.

[12] B. Graybeal, Ultra-high Performance Concrete Composite Connections for Precast Concrete Bridge Decks, Federal Highway Administration, Washington, DC, USA, FHWAHRT-12-041, 2012.

[13] J. Hegger, M. Feldmann, S. Rauscher, and O. Hechler, "Highperformance materials in composite construction," Structural Engineering International, vol. 19, no. 4, pp. 438-446, 2009.

[14] J. Y. Kang, J. S. Park, W. T. Jung, and M. S. Keum, "Evaluation of the shear strength of perfobond rib connectors in ultra high 
performance concrete," Engineering, vol. 06, no. 13, pp. 989-999, 2014.

[15] S. He, Z. Fang, and A. S. Mosallam, "Push-out tests for perfobond strip connectors with UHPC grout in the joints of steel-concrete hybrid bridge girders," Engineering Structures, vol. 135, pp. 177-190, 2017.

[16] D. Kruszewski, K. Wille, and A. E. Zaghi, "Push-out behavior of headed shear studs welded on thin plates and embedded in UHPC," Engineering Structures, vol. 173, pp. 429-441, 2018.

[17] J. Wang, J. Qi, T. Tong, Q. Xu, and H. Xiu, "Static behavior of large stud shear connectors in steel-UHPC composite structures," Engineering Structures, vol. 178, pp. 534-542, 2019.

[18] GB50010-2010, Code for Design of Concrete Structures, China Building Industry Press, Beijing, China, 2010.

[19] J. Vianna, S. Andrade, P. Vellasco, and L. Costa-Neves, "Experimental study of perfobond shear connectors in composite construction," Journal of Constructional Steel Research, vol. 81, pp. 62-75, 2013.

[20] Fib (Fédération Internationale Du Béton), Model Code for Concrete Structures, Fédération Internationale du Béton, Lausanne, Switzerland, 2010.

[21] G. Minafò, "An interface model for the analysis of the compressive behaviour of RC columns strengthened by steel jackets," Structural Engineering and Mechanics, vol. 71, no. 3, pp. 233-244, 2019.

[22] G. Minafò, A. F. Siciliano, and M. Fossetti, "Modelling loadtransmission mechanisms in axially loaded RC columns retrofitted with steel jackets," in Proceedings of the 1st International Conference on Numerical Modelling in Engineering, pp. 90-111, Ghent, Belgium, August 2018.

[23] Z. Q. He, C. Ou, F. Tian, and Z. Liu, "Experimental behavior of steel-concrete composite girders with UHPC-grout strip shear connection," Buildings, vol. 11, no. 5, 2021. 